\title{
Christian faith and unorthodox belief
}

\author{
Patrick Giddy \\ University of KwaZulu-Natal \\ Durban, South Africa \\ jpgiddy@gmail.com
}

\begin{abstract}
In his autobiographical account of his theology Augustine Shutte (2016) clarifies how his understanding of the Christian faith has, finally, put him in conflict with orthodoxy. More recently he explains that "in the absolute distinction between creator and creature it is appropriate to see God alone (Father, Word and Spirit) on one side and Jesus and me and you on the other." This affords us a useful starting point for a discussion of a Christian faith marked by unorthodoxy. As foil for the discussion I take Bart Ehrman's thesis that the early development of the understanding of Jesus as "uniquely divine" is unjustified, and this undermines Christian faith. I argue in response that the cognitional dimension is only one aspect of religious faith; secondly I unpack the structural side of orthodoxy; and thirdly I introduce Shutte's concept of salvation in terms of a fundamental human need. The uniqueness of God's presence in Jesus implies a sectarianism unhelpful in a plural culture.
\end{abstract}

\section{Keywords}

Bart Ehrman; Augustine Shutte; orthodoxy; salvation; secular age; Christian faith

\section{Introduction}

In his "autobiographical introduction" to his collected theology papers published in the Stellenbosch Theological Journal (2016), and reflecting back on his fifty years of theological research, Augustine Shutte (d. 2016) remarks of his essay on ecumenism that he affirms there "the uniqueness of God's presence in Jesus, and thus in the church, in a way that I no longer would." In his notebooks, which happily I have to hand, he explains further that this changed view is based on his understanding of personal presence. "Personal presence is a relational concept, depending on both members of 
that relationship. It is from our side that there is a difference between God's presence in Jesus and God's presence in us. From God's side, as it were, there is no difference." This "no difference" is what he now sees as nonorthodox. He bases his understanding on two grounds, his philosophical anthropology outlining the intersubjective nature of being human, and growing as a person, an interpretive key to how Jesus saves us; and secondly, on the scholastic notion of the incommensurability of God and universe, allowing for a more nuanced answer to the question that Jesus in the gospel account posed to his followers, "Who do you say I am?"

If orthodoxy is set by belief in Jesus' "uniquely divine" status then we have here, in Shutte's account, a useful starting point for a discussion of a Christian faith marked by unorthodoxy. As convenient foil for the discussion I take the thesis of Bart Ehrman to the effect that a properly scholarly unpacking of the early development of the Church's understanding of Jesus, that is to say as "uniquely divine," reveals this development as unjustified and undermines the central reason for Christian faith. This is not Shutte's understanding and calls for a response.

My discussion is threefold. I argue firstly that the cognitional side of discipleship - "belief" - is only one dimension of religious faith; secondly, I unpack the structural and ecclesial side of orthodoxy; and thirdly, I introduce Shutte's concept of salvation in terms of a fundamental human need.

The idea of the uniqueness of God's presence in Jesus, and thus in the church, implies a hegemonic sectarianism unhelpful in a culture that recognizes a plurality of expressions of salvation understood in this way. But this implication does not form part of Shutte's earlier theological understanding, and I intend this discussion here as background to the unorthodoxy that I extract from his unpublished notebooks. The further argument in favour of unorthodoxy, going beyond his formulations in his published writings and centred on the key notion of the incommensurability of God and universe, is matter for a future essay.

The idea of "orthodoxy" refers back to the Creeds of the church. But their import would seem to vary somewhat between Protestant and Catholic understandings of Christian faith. In the former case greater emphasis is placed on the "fundamentals" of belief, for example as formulated by 
conservative evangelicals in the late nineteenth century: the inerrancy of scripture, the divinity of Jesus, the satisfaction theory of the atonement, the virgin birth and the physical resurrection of Jesus (Haight 2005a: 299). In the latter case the role of the pronouncements of the ecclesial authorities is more prominent. Since Shutte is on the Catholic side of things, my example is the "Notification" of the Congregation for the Doctrine of the Faith in the Catholic church issued in respect of the "doctrinal errors" in Roger Haight's 1999 book, Jesus Symbol of God that discusses, among others, what Haight elsewhere (2005b: 29, footnote) terms an "imaginative fixation on Jesus' being God.” In contrast, this authoritative body also encourages, as the Catholic Theology Society of America notes (in Haight 1999: 516) the "process of serious, systematic, internal criticism" of theology, a process undermined by this "Notification" (Haight has had restrictions placed on his eligibility to teach theology), which could then plausibly be judged - as the ball is returned to the other court - as itself contravening the "orthopraxis" of the religion.

\section{Ehrman - How Jesus became God}

In his popular 2014 book, How Jesus became God, the scripture scholar Bart Ehrman argues as follows:

Premise 1: Either Jesus was "uniquely divine," or he was not.

Premise 2: The former position is the central belief of the Christian religion.

Premise 3: If the latter position is true, the central belief of the Christian religion is false.

Premise 4: But the idea of the divinity of Jesus can be shown to be based on very weak grounds.

Conclusion: The central belief of Christianity is false.

To which can be added, as an implicit corollary, the suggestion that no reasonable person should adhere to a movement based on a falsehood. Hence - also implicit in the thesis of the book - Ehrman himself $(2014,354)$ has been reasonable in dropping his adherence to the Christian religion. 
The major part of the book is concerned with showing the reasonableness of Premise 4, that the grounds for thinking Jesus is divine are very weak. First, the notion that Jesus was divine was written into the text by people "who already 'knew' that Jesus had been exalted to heaven" (Ehrman 2014: 206). Ehrman continues, "As the storytellers told the stories of Jesus' earthly career, year after year and decade after decade, they did not separate who Jesus was after his death - the one who had been exalted to heaven - from who he was during his life. And so, their belief in the exalted Jesus affected the ways they told their stories about him" (2014: 206).

Secondly, it is, he says, the "visionary experiences," issuing in the belief in Jesus' resurrection, that "initially led the followers of Jesus ... to believe that Jesus had been exalted to heaven and made to sit at the right hand of God as his unique Son. These beliefs were the first Christologies - the first understanding that Jesus was a divine being." (Ehrman 2014: 7) And Ehrman insists that it was only after his death "that the man Jesus came to be thought of as God on earth" (2014: 18).

Thirdly, Ehrman argues (2014: 8), the move was made to affirm not only that Jesus had been exalted to the level of divinity, but that he was "a preexistent divine being with God before he came to earth as a human." Fourthly, Ehrman traces the further development that happened, he argues, through the intervention of the emperor Constantine, who pushed through one particular formulation in the interests of unity in the Empire. The result was the Nicene Creed, henceforth the mark of orthodoxy. Implicit in this account of Ehrman's is the idea that the creedal formulations are, to the extent that they were brought into being for non-religious purposes, discredited.

A fifth point is that the two central Christian ideas associated with the early councils seem to flout standards of logic and rationality (Ehrman terms them "ortho-paradoxes"), the idea of the god as both three and one, and the idea of Jesus as both human and divine. This further undermines the reasonableness of the religious faith.

So, how did the idea of Jesus as divine come about? "How did an apocalyptic prophet from the backwaters of rural Galilee, crucified for crimes against the state, come to be thought of as equal to the One God Almighty, maker of all things? How did Jesus - in the minds and hearts of his later followers - 
come to be God?" (Ehrman 2014: 45) According to Ehrman, there were, in the Roman cultural context of the time, many gradations of god, and Jesus could at first have been thought of unproblematically as a bit god-like. There was "a kind of pyramid of power, grandeur, and deity" (2014: 40) and with perhaps one ultimate deity at the pinnacle, but other tiers were populated with divine beings, with gods of love, war, weather, and so on. A few special humans might also be or become gods. The problem arose with the notion, after the fourth century C.E., of the generally unbridgeable chasm between being god-like and being human-like (2014: 43). Jesus has, now, to be one or the other.

I do not judge this account plausible. In his review of Ehrman's book, Bernard (2015: 185) argues that the effect of the visions underdetermines the decision to flout the traditional monotheism of the Jewish tradition: more than this was at play in the genesis of the new faith. My point is different: Ehrman's historical narrative seems to take the Roman understanding of god as unproblematically a framework to "place" the new religion's god. But this understanding would seem to have been under threat at least since the time of Socrates, executed for his "atheism" and for misleading the youth, and unable to survive the process of critical engagement with the tradition that marked Greek philosophy. Furthermore, while it is true that the Christian approach was seen - by the religious authorities - as dissenting from the Jewish traditional view, as Bernard points out, it could be that what was being dissented from was an unhelpful version of the tradition, and that the Christians were affirming a more authentic, insightful, understanding of the god, in line with the prophetic movement. There does not seem necessarily an opposition between monotheism and what the Christians took to be true of Jesus.

Furthermore, the whole notion of "visionary experiences" can be problematized. Experience is never simply of one kind, a passive kind of thing, that can be judged authentic if what is received truly corresponds to what is out there, or not - say, a mirage. Rather, experience is always conditioned by intentionality. To see properly I deliberately turn my head, focus. A flock of birds flies overhead: I see a flock of birds, my ornithologist friend well acquainted with this region, sees climate change. Same sensation, different perception. Given this kind of intentionality, the 
question would seem to be, not, does the vision correspond to what is really there, but rather, is the perception truly justified?

Ehrman argues that the grounds for thinking Jesus divine are weak. But even if this is true, his conclusion does not necessarily follow, namely that the grounds for holding to the Christian faith are thereby fatally undermined. We can trace how the followers formulated their understanding of the place Jesus had in their lives. But there is a significant difference between exactly what one believes, "belief that," and the total attitude of the person, of intellect, will, and feeling, "belief in," that is at issue in religion. Religious faith entails a commitment that has a cognitional dimension (one should not keep one's eyes shut to new insights) but also an affective element. Thus, for a short while belief in the new South African president seemed to engender a volitional change captured in the Ramaphosa's phrase (borrowed from the late Hugh Masekela), "send me" (Thuma mina). This might change when the "belief that" is what one previously thought changes, as it seemed to do in our example, but this is nevertheless one dimension only of the commitment. It is not the single decisive factor. ${ }^{1}$

Let us suppose that religion is a response to a natural human need, and a (often unrecognized) desire. The god of any religion will be understood as meeting that need and will take its character from how that need is perceived. In a desert the god's main characteristic might be "bringer of the rain." Now if we can identify a human need that is not simply cultural but natural, a need that human persons have by nature but cannot of their own fulfil, then we have a basis for judging the various religions. Let us suppose, further, that the difficulties of understanding one's deepest wants, and of living one's life in accordance with them, so as to grow more integrated, and hence generous with oneself, is that need. We suppose, in other words, we have identified an existential impasse. Then the religion cannot be based on one's understanding, simply, in other words, "belief that." If the "belief that"

1 For Joseph Moingt, "belief in" is what he terms "faith" (foi), an act of trusting in Christ and of following the way of salvation he has himself traced; "belief that" is what he terms "belief" (croyance), that is to say an assent to one or other doctrine considered central - and in this Moingt shows himself in agreement with our own distinction and not necessarily having an effect on the whole of one's life. Moingt refers to surveys showing large groups of Christians for whom belief in the Devil is the criterion of faith, for others it is the resurrection of the dead, and so on. (Moingt 2010: 34-35). 
is shown to be false (the god does not bring rain, in any meaningful sense of this), it is not necessarily the case that the religion should be dropped by any reasonable person. It might be that one's understanding simply needs further growth. Understanding the limits of one's understanding is clearly part of the religious faith. One was mistaken about the central need giving rise to the religion, a need by nature and therefore, in this tradition, created by the god. It does not mean such a central need does not exist. It does mean the religious understanding requires development.

This has the further implication that how the religious faith is expressed will always be a matter of degree of adequacy and influenced by the culture in which it has been developed. Haight (2004: 258), for example, sees the creedal formulations of Nicaea and Chalcedon as examples of inculturation, and so very much a process that always calls for a new response - and this throws light on Ehrman's problem with the "ortho-paradoxes" of these early Christian councils. Ehrman wants to dismiss "liberal Christians" who do not take all these statements as literally true. He argues that at the time they were formulated "the basic literal meaning of these statements mattered" (2014: 325). But seeing the formulations in terms of a process of historical inculturation puts the shoe on the other foot: the authentic believer must try to respond to our (very different) cultural context. As Haight sums it up, "When the formulations of the central doctrines of Christianity are recognized as examples of inculturation, they no longer appear as absolute or a-historical propositions, but as classic and paradigmatic examples of the principle of inculturation," and which, Haight adds, cannot be bypassed because of the role they play in defining Christian belief (Haight 2005b: 258).

Ehrman himself finds he can only assent to the assertion that Jesus was "crucified under Pontius Pilate, suffered death and was buried" (2014: 325). This kind of common sense limiting, or scepticism, may be linked to a further framing of Shutte's understanding of the Christian faith in contemporary culture, namely the neglect of transcendence that often accompanies a scientific mentality - what Marilynn Robinson (2010) calls the "absence of mind." Scientism names the tendency to allow only knowledge gained through the sciences, thus eliding the transcendence of such causalities in our ability to know to some extent how things really are (not just from my point of view) and to act on how we judge is the 
way forward of real value, that is to say, responsibly. The dominance of technology makes us think of ourselves as acting on the world, obscuring how we freely act on ourselves, forming character, well or more often not so well. Furthermore, acting on the world we forget our interdependence, a notion engrained in pre-modern African culture and unpacked at length by Shutte in his Philosophy for Africa (1993) and Ubuntu (2001). And this issues in another blind spot associated with contemporary liberal culture, namely an unrealistic individualism. In both cases religion has a role to play: our transcendence, as we will discuss below, can only properly be explained as sourced by a non-finite power not part of the nexus of forces that codetermine the universe. ${ }^{2}$

To close this brief discussion of Ehrman's book we can note that the historical consciousness that frames our contemporary approach to religious faith throws further light on Ehrman's first point, namely that the gospel narratives were written in the light of the later experiences of the writers. Only a fundamentalist, a-historical, kind of thinking would suppose that this undermines faith rather than maturing it as one is enabled to share more fully in the gospel writers' own appreciation of their faith. Similarly, it is true that John's gospel does present a "pre-existent" Logos incarnate in Jesus. But - referring here to our historical awareness no person brought up in the Jewish tradition would think that there was another "divine being" alongside Yahweh. We have to suppose that there is another way of understanding this famous prologue to John's gospel. Haight (1999: 152-178) makes the important point that there was an early pluralism of ways of making sense of Jesus as messiah, only one of which is that formulated by John.

Ehrman's fourth point - unpacking the political forces at work in pronouncing finality on the particular formulation of Christian belief at Nicaea - has to do with a structural problem circumscribing the whole discussion on how we should take "orthodoxy," and we look at this in the following section.

2 Something disputed by Luc Ferry (2011) in his excellent discussion of transcendence in postmodern humanism, Comprendre à Vivre (Understanding how to live), a theme not evident in the English title, A Brief History of Thought. 


\section{A structural problem for theological development}

Our own cultural context can be characterized (without implying a noncritical assent) by the set of values associated with modernity, in particular individual conscience, responsibility and democratic participation that upholds the equal dignity of all. Insofar as the ecclesiastical authorities see themselves as "franchised" these values are likely to be flouted, at least in practice. A franchised clerical class refers to the idea of a supernaturally bestowed exclusive right to be the authoritative spokesperson for the Christian faith and dispenser of grace. Mackey links this structural institutional problem, a block to the proper development of "belief that," to "the ecclesiology that characterizes the superstructure model of grace above and beyond nature, and of revelation above and beyond history," such that grace and truth, it is thought, come exclusively with Jesus, paradigm of an instance of an interventionist god. ${ }^{3}$ The upshot of this is the claim of some leadership groups within the churches to have "the privilege and responsibility to make this grace and truth known and available to all nations and all ages ..." (2006: 20). And in practice this overrides the freedom of scholars to suggest new formulations of the Christian faith. (Mackey is speaking within the context of the Roman Catholic Church; the fact that Ehrman, a Reformed Christian, or a former one, finds a similar petrification of "belief that" in his own ecclesial community, is of course interesting. ${ }^{4}$ ) Joseph Moingt, a French Jesuit, sees this very clearly; in other words that reform means changing structures so that discussion, debate and maturing of thought may take place. I am quoting from the useful summary of Moingt's point of view given by Jean-Pol Gallez in his talk to CCBF (Conférence catholique des baptisés francophones).

As we can see, the problem is not of ordaining women or not, of allowing priests to marry or not but of foreseeing a new way of living-together

3 For an account of how one may understand the unique historical place of Jesus in Christian faith within a framework of non-interventionist divine action, see Bill Stoeger (2008).

4 For one explanation of this, see Mackey's (2006: 15) remarks on Calvin and the idea that it is original sin that necessitates special arrangements for access to the god, through the forgiveness of sins. 
within the Church - a new co-citizenship - far from any clerical logic. Moingt argues as follows:

I think that the church's salvation does not imply the reinforcing of the ranks of the clergy. It first of all consists in restoring the equality at its base, by giving back to the faithful the right of speaking up that they enjoyed long ago, and by letting it spread all over, so that the Christians may take responsibilities, and feel rightly in charge of their Church and of its survival in the world. I do not believe, as far as I am concerned, that the Church might disappear because of a lack of consecrated people, of a lack of priests.

We understand better now why Moingt places the matter of the priesthood at the heart of what he calls a communication problem between the Church and the world. Because of its early collusion with the secular powers the Church got used to functioning within a domination-type of relationship which fails to honour the evangelical paradox of exercising power without domination or inequality. The distinction between the laity and clergy emerged and developed along the centuries, and it restricted the right of proclaiming the Gospel to the clergy. If the Church and the society functioned together within the framework of the worldly power, the communication between them worked pretty well. In a world which was almost totally Christian, all could hear its message. But, in a western democratized society which has left religion behind, the way authority is practiced in the Church is felt as non-egalitarian, and the Word cannot any longer be proclaimed to the world because the religious model which bears it has run out of steam (Gallez 2017: 9; my translation).

The problem can be put in another way. Karl Rahner, a peritus at the Second Vatican Council (1962-5), writes that while the orthodoxy can be justified - say, Jesus as the Eternal Son of God being put to death and thereby atoning for sin (as only God's Son could), thus a sacrifice - still there is today more: there is a feeling of 'metaphysical overload' in these traditional formulae, and this disquiet is perfectly understandable. In one long German-type sentence Rahner (1983: 61) concludes: 
If a Christian can trustingly and confidently say, "In Jesus of Nazareth, in his life, his teaching, his catastrophic death, his victory (which we call his resurrection), God has given me himself - his forgiveness, his own life, above and beyond all finite fulfilment" - if a Christian believes that this self-bestowal of God's is unconditional, irreversible, and definitive for his own part, and that it can never be superseded or surpassed in some new age to come - for indeed, as God's last word it can no longer be superseded - if a Christian is engaged and committed to this in a free outpouring of faith, and allows this matchless hope more validity than all doubts, scepticism, and reservations - then he or she is an orthodox Christian.

Be that as it may, there are no canonically sanctioned liturgies where this way of seeing Jesus as saviour gets expression in the churches. A person holding this version of their faith is, in other words, going to be marginalized. ${ }^{5}$

The structural problem for theology is well canvassed by Shutte in his collected theological essays. A legalism would focus on the constitution of the organisation and the well-formulated rules of membership, differentiated between clergy (the franchised clergy) and ordinary members. ${ }^{6}$ But a new vision is expressed in the Vatican II conception of the church as "sign and instrument of union with God and of the unity of humankind" (LG 1, in Flannery 1975: 350). In spite of this, and in contrast, the 1985 Synod of Bishops of England and Wales' document on The Laity argues that the laity are both members of society and of the church (1985: 21); the implication is that this is not the case for clergy - they are outside of

5 The need for a less hegemonic authority structure can be appreciated perhaps most immediately from those parts of the globe furthest from the governing centre, as Bergoglio - now Francis, Bishop of Rome - well understood. "The fruitful universality which integrates and respects differences, he writes, was replaced by an absorbent metropolitan hegemony, of the most domineering kind" (quoted in Ivereigh, 2014: 63). $\mathrm{He}$ is describing the 18th century overturning of the Jesuit reductions in the Spanish colonies by a cold rationalism of the monarch in Madrid. But as Ivereigh points out, the implications are far broader: this kind of hegemony should be resisted, under the flag of a common-sense message from the heart.

6 See, in this regard, various essays of Shutte $(1970 ; 1976 ; 1978 ; 1982 ; 1999)$. These essays are found in The Christian God and referenced individually in Shutte's "autobiographical introduction" (2016), accessible online with links to the original published papers. See also Shutte 1993, “The World's Underground," Chap 9 of The Mystery of Humanity. 
normal society. ${ }^{7}$ A legalism of this kind blocks real ecumenical work as well as the possibility of dialogue between religions. It also betrays an outdated vision of religious spirituality, one that has not yet moved on from the age of an evangelical kind of spirituality (accompanied by colonialism) that replaced the flight from the world that gave birth to the earlier monastic spiritual vision. Contemporary spirituality, in contrast, influenced by a historical and evolutionary consciousness, is oriented to the world as our home, and it is a culturally plural world.

It is in thinking through Christian faith in the context of religious plurality that we reach a point of conflict with orthodoxy. Insofar as God's presence in Jesus is of a different order to his presence in anyone else, what the Church signifies to humankind cannot but be a kind of sectarianism. Shutte (2016: 242) later, as mentioned above, comments on his essay on ecumenism that he affirms here "the uniqueness of God's presence in Jesus, and thus in the church, in a way that I no longer would." He explains that the term "presence" is ambiguous. For us, "from our side," God's presence in Jesus is historically definitive, making us what we are. At the same time, faith in Jesus is a faith in humankind; it opens us up to this latter faith. God is present in us too, and in all persons. So, we don't "possess" God, in our Jesus; "from God's side, as it were, there is no difference" between God's presence in Jesus and in ourselves. And as we are, so are others: in our Christian faith we are aligning ourselves with every person in any culture. The strength to do so is sourced in our Christian faith.

The non-orthodoxy is summarized in Shutte's notebook entry: "In the absolute distinction between creator and creature it is appropriate to see God alone (Father, Word and Spirit) on one side and Jesus and me and you on the other. We, with Jesus, depend on, cling to and move towards God. In the New Testament and in Eastern Christianity, this is the basic pattern: prayer to the Father with and through the Son and in the Holy Spirit. It

7 In his Christo-fiction (2015) - the title itself revealing a distancing from orthodoxy François Laruelle, identifying himself as a Lutheran, claims rights for philosophy over against ecclesiastical structures, but the book is so obscure as to be of little use for our project. 
is never prayer to, or life towards three persons each of whom are equally God."”

To sum up, the problem would seem to be that of being a normal member of our contemporary pluralist culture who also belongs to the religious tradition. It is a problem that Ehrman thinks not resolvable. Shutte disagrees, and his disagreement, I will now argue, is founded on his understanding of how Jesus saves us. ${ }^{9}$

\section{How Jesus saves us}

We have introduced above the suggestion that religion is a response to a natural human need but one that human persons by the logic of things seem unable to meet. This is the interpretive framework that Shutte terms "the human predicament" and that he uses in order to develop his understanding of how Jesus saves us. In his essay with this title (Shutte 1986), the basic idea is that of an impasse in our efforts at self-realisation: our lack of adequate knowledge about our deepest needs, the need to grow in self-knowledge and in self-donation, issues in choices that lock us into patterns of behaviour that do not manifest the kind of openness of heart that is needed if we are actually to learn about ourselves. But only that openness of will, can facilitate growth in self-knowledge, and only proper self-knowledge would issue in choices affirming this openness. So personal growth is blocked. At least it would seem to be. If then personal growth does occur, there is the question of its provenance, and Shutte puts forward as an explanation a model of intersubjective transactions, the more developed person turning to offer his or her self-understanding and integrated system of habits, to the less developed. The "solution" is a sharing of lives.

8 Moingt has a similar formula for Christian faith: "the rule that we address our prayers to God our Father through Jesus Christ his Son, our Saviour, in the Holy Spirit that lives in us and gathers us in the same faith" (Moingt 2010: 59, my translation).

9 There are multiple ways of trying to inculturate the Christian faith into contemporary culture. For example, Cynthia Bourgeault (2008: 21) moves away from the idea of being "saved" as key to Christian faith, because it is often linked to the unhelpful idea of the "utterly depraved" condition of human persons, not a view that is seen as helpful today. She replaces soteriology with sophiology, Jesus as a wisdom teacher. But here we are problematizing the acquisition of wisdom, and thus its provenance in Jesus, or anyone. 
In this way we can make sense of the Christian God - for clearly all persons are in the same predicament, unable to grow, unable to help others grow. At least insofar as persons are strictly speaking finite, constrained by their interdependency. We grow only through the influence on us of another person, more self-aware and integrated than ourselves, and who shares their self-understanding and hierarchy of values with us in a way that (because we share a common human nature) we cannot but find attractive. The actual experience of growth in us reveals a source that, by the logic of things, operates within finite persons but does not share the condition of finite persons, i.e. hobbled by their own imperious need to grow. ${ }^{10}$ This is the mystery of being saved, identified by Christians in Jesus of Nazareth.

What we have in the New Testament is an account, in pre-secular language, of the beneficial interaction between Jesus and his followers. In bare outline we are given the fact that Jesus taught, attracted a following, and that this following attested to the transformative influence of this person in their lives. We can see how Shutte's approach suits a secular culture. ${ }^{11}$ In a sacral worldview spiritual reality are alongside earthly, the universe is static, structured hierarchically (reflecting the feudal social order). A premodern view of the cosmos sees "man" as occupying a place below the heavens, above the beasts. And in terms of this place assigned to us the chief virtue actualizing human potential, is obedience, in fact recognizing one's "place." This "how you fit in" clearly suits a feudal way of seeing things, and it is given an ecclesial blessing by virtue of its mirroring of the cosmic reality as seen at the time. A secular society has a different approach. The secular worldview is unitary - there is not up there and down here - but developing, and with a transcendent dimension seen in the capacities of each person to participate, to take responsibility for their lives. This selftranscendence is the fundamental human value, not obedience. It is where religious faith is focused. Our attention moves to the social structures and habits of behaviour that facilitate and enable this self-transcendence,

10 The result is a debilitating sense of being a failure, from which we are liberated, in Sebastian Moore's analysis, by identifying with the "clown king" who nevertheless comes through into new life. Moore is very much in line with Shutte's account, moving away from the "God is on our side" kind of thinking, the idea, as Moore puts it (1968: 38) that "our man Jesus was right."

11 For an extended explanation of this, see Shutte (2015). 
for example, education, democratic participation, and the proper care of children through responsible parenting. None of these were at the centre of pre-secular culture and yet are arguably central to Christian faith.

\section{Conclusion}

If this is how a Jesus faith can bring about our salvation, then the "placing" of Jesus in terms of a cosmology of "up there" and "down here" will obscure any insights into the liberating potential of the religion. The latter depends on recognizing the potential for a saving intersubjective transaction in all our personal encounters. So, the religious focus of Christians must not be directed elsewhere than to human experience and in particular selftranscendence. There is little doubt that this will be seen as challenging the orthodox position and at the same time the structures of authority that are linked to that orthodox understanding. ${ }^{12}$ But seeing Jesus in this way as a model for God's action in the world and symbol for us of our own participation, links in with the outlook of a secular culture that can prioritize friendship over a legalism.

A secular culture would be expected to generate many for whom orthodox Christian faith is an obstacle but have faith in human transcendence; a good example is French philosopher Luc Ferry (2011). The critical research of Christian theologians has not gone unnoticed, and at least in the Francophone world an important shift has occurred. The current openness to this kind of dialogue can be contrasted with the situation of some years ago where the very idea of Christian faith was intolerable to many, a scandal among French intellectuals. ${ }^{13}$ It is of interest that, more recently, where fundamentalist approaches to Christianity have some not negligible social power, namely North America, is where the more extreme

12 The resistance is articulated at length, without the philosophical and theological analysis we have given, by the Flemish Jesuit Roger Lenaers, whose Otro Cristianismo es Posible (2008) is making an impact in Latin America. And this more activist approach is echoed by other writers such as Mackey (2006), Spong (2007), and Küng (2013).

13 Guillemin (1982) describes the scandal as a public exposé of what he terms "The Jesus Affair." Members of the educated public are affronted by "the deplorable superstitions that we thought to have been put to bed by the eighteenth-century thinkers" (Guillemin 1982: 9, my translation). 
anti-religion attitudes - of the Richard Dawkins, Christopher Hitchens, and Daniel Dennett variety - find an audience.

Ehrman's argument has not been fully answered. This could be done more adequately by unpacking the key insight - associated with the Axial Age and the prophetic tradition - into the incommensurability of God and universe. Based on this the move from orthodoxy can be more fully expanded, as Shutte has done, and, as I have indicated, this is a matter for a future article.

I can conclude with one of Augustine Shutte's "poems for the human spirit" (Shutte 2017: 48).

\section{My Psalm 22}

My God, my God, why have you forsaken me?

You are far from my plea and the cry of my distress.

Oh my God, I call by day and you give me no reply;

I call by night and I find no peace.

Yet you, O God, are goodness itself.

It was you in whom Jesus put his trust.

Trusted you even on the cross

And through his death you gave him life

Eternal life with you.

But I am not Jesus, not a good man.

People think nothing of me, think little of my faith.

"If his faith is real, why is he such a failure?

His religion is only a sign of his weakness."

But I know it was you that gave me life. 
And it was you who all my life has helped me to grow,

Blessed me with the love of friends

Lit the fire of faith within my heart

And kept it alive in spite of doubt and fear.

For I do doubt. Those who write me off

Have authority behind them, and common sense.

Sometimes I feel quite alone, an outsider

To the multitude of true believers

And cast off by those on whom I depend.

Do not leave me quite alone my God:

All my courage and my strength

And what faith I have, comes from you.

If you give me something of the insight

The knowledge of you, your own true Word

You gave to Jesus, something of the inspiration

Of your Spirit you gave to him,

Then I can hope to be a true son of yours.

\section{References}

Bernard, D. 2015. Review of B. Ehrman, "How Jesus Became God." Religion \& Theology 22: 179-185.

Bourgeault, C. 2008. The Wisdom Jesus. London: Shambhala. 
Catholic Bishops Conference of England and Wales, 1985. The Laity. London: Catholic Truth Society.

Ehrman, B. 2014. How Jesus Became God. New York: HarperOne.

Ferry, L. 2011. A Brief History of Thought. Tr. T. Cuffe. New York: Harper.

Flannery, A. 1975. (ed.) The Documents of Vatican II. New York: Pillar Books.

Gallez, J-P. 2017. “Refonder l'Eglise: l'appel de J. Moingt à tous les baptisés." Talk to CCBF. [Online]. Available: http://www.baptises.fr/ sites/default/files/document/ccbf-21.10.17-jp_gallez

Giddy, P. 2016. “Augustine Shutte's Autobiographical Account of his Christian Theology." Stellenbosch Theological Journal 2: 227-256.

Guillemin, H. 1982. L'affaire Jésus. Paris: Seuil.

Haight, R. 1999. Jesus Symbol of God. New York: Orbis.

Haight, R. 2004. Christian Community in History Volume 1: Historical Ecclesiology. New York: Continuum.

Haight, R. 2005a. Christian Community in History Volume 2: Comparative Ecclesiology. New York: Continuum.

Haight, R. 2005b. The Future of Christology. New York: Continuum.

Ivereigh, A. 2014. The Great Reformer. Francis and the making of a radical Pope. London: Allen and Unwin.

Küng, H. 2013. Can We Save the Catholic Church? Tr. T. Riplinger. London: William Collins.

Laruelle, F. 2015. Christo-fiction. The ruins of Athens and Jerusalem. Tr. R. Mackay. New York: Columbia University Press.

Lenaers, R. 2008. Otro Cristianismo es Posible. Fe en lenguaje de modernidad. Tr. M. Ossa. Quito: Abya Yala. [Online]. Available: http://www.digitalrespository.unm.edu/

Mackey, J. 2006. Christianity and Creation. New York: Continuum.

Moingt, J. 2010. Croire Comme Même. Paris: Editions Proche. 
Moore, S. 1968. No Exit. London: Newman Press.

Rahner, K. 1983. The Love of Jesus and the Love of Neighbour. Tr. R. Barr. Slough: St Paul Publications.

Robinson, M. 2014. Absence of Mind. New Haven: Yale University Press.

Shutte, A. 1970. “Salvation as Oop Gesprek.” New Blackfriars 51: 572-577.

—. 1976. "Religious Laws: The Christian Problem." Journal of Theology for Southern Africa 15: 39-48.

—. 1978. “Do Lay People Have a Vocation?.” Unpublished.

—. 1982. "Ecumenism Today." Unpublished.

—. 1986. "How Jesus Saves Us." Journal of Theology for Southern Africa 55: $3-14$.

-. 1993a Philosophy for Africa. Cape Town: University of Cape Town Press.

—. 1993b The Mystery of Humanity. Cape Town: Snailpress.

—. 1999. "Dialogue Between Religions.” Unpublished.

-. 2001. Ubuntu. An ethic for a new South Africa. Pietermaritzburg: Cluster Publications.

—. 2015. "Conflict and Religion: Secularity as Standard for Authentic Religion," in J. Seibt and J. Garsdal (eds), How is Global Dialogue Possible? Berlin: De Gruyter, 420-449.

-. No date. The Christian God. Essays on Theology. Unpublished.

—. No date. Notebooks. Unpublished.

-. 2017. The Way Home. Poems for the human spirit. Ed. P. Giddy, B. Greene and A. Neale-Shutte. Cape Town: Kirkwood Press.

Spong, J. S. 2007. Jesus for the Non-Religious. New York: HarperOne.

Stoeger, W. 2008. "Conceiving Divine Action in a Dynamic Universe," in Russell, R., Stoeger, W. and Murphy, N. (eds.), Scientific Perspectives on Divine Action. Vatican: Vatican Observatory Publications, 225-47. 